\title{
Think tank scene in Finland: Nothing spectacular?
}

\author{
Lotta Lounasmeri
}

\section{Think tanks spreading to the Nordic countries - what about Finland?}

In the last two decades of the 20th century, think tanks proliferated dramatically, and the industry has experienced major growth globally (Hart \& Vromen 2008, 137; Stone 2007, 264). Countries where think tanks were already present, such as the United States (US), Britain, Sweden, Canada, Japan, Austria and Germany, have experienced additional growth. In the long run, the global political and economic environments have gone through substantial changes along with technological developments, such as digitalization and the spread of the Internet. Together, these phenomena have generated a demand for 'usable knowledge' concerning new policy challenges and opportunities in societies. (Stone 2007.)

The term 'think tank' has become popular worldwide, and Stone $(2007,262)$ sees the fact that so many organizations globally call themselves 'think tanks' as symbolic of the effectiveness of the label. It has also been applied to hybrid organizations and ones that are not independent of the state, corporate or other interests (Stone 2007, 265). The US still represents the forerunner of the think tank scene (McGann \& Johnson 2005). The United Kingdom (UK) and Germany have the most populous think tank landscapes and probably the most active think tank culture in Europe (Braml 2004). Thunert (2004), for example, counted 130 think tanks in Germany and about 100 in the UK.

In broad terms, think tanks can be defined as institutes devoted to producing research-based policy arguments and offering them in the policy-making process (Hart \& Vromen 2008, 135). The United Nations Development Programme (UNDP) definition of think tanks (UNDP 2003, 6) is presented by Stone (2007), who categorize them as organizations engaged in research and advocacy on any matter related to public policy. Thus, think tanks advocate ideas, maintain and develop policy networks and provide expertise to policy-makers (Stone 2000). Keohane and Nye (1998, 136) see 'think tank' as an informal brand name for organizations able to 'reliably edit and credibly validate information.'

Political party-affiliated think tanks are almost nonexistent in the United States, but they are the dominant model in Europe (McGann 2007, 12). According to Stone, the dominance of AngloAmerican perspectives of what a think tank is obscures the diversity and hybrid forms of think tanks that have emerged recently. As Stone sees it, in any particular country, the historical circumstances, 
political culture and legal traditions, along with the character of the regime in power, determine think tank development (Stone 2007, 261).

In the Nordic countries, the large-scale phenomenon of a growing think tank scene occurred in the 2000s. The underlying reasons presented for this emergence of think tanks include the weakening of the corporatist system as well as the growing influence of the media (mediatization) and the rise of promotional logic in these societies (Allern 2011; Blach-Ørsten \& Kristensen 2016; Rommetvedt et al. 2012; Tyllström 2013; see also Cottle 2003; Davis 2007). The Nordic phenomenon seems to be limited to the rise of policy advocacy think tanks and think tanks associated with political parties, as they represent ideologically-driven, financially and/or organizationally connected institutes, which often devote at least as much attention to disseminating ideas as to producing them (see Braml 2006; McGann \& Weaver 2000, 6-12). Apart from the Finnish business-funded EVA founded in 1974, advocacy think tanks in Finland are a recent phenomenon. Think tanks associated with political parties were first launched as recently as 2005, as government funding for this type of activity was initiated. The leftist Kalevi Sorsa Foundation and the Left Forum were founded then. Naturally, research organizations have been funded by different interest groups in Finnish society, such as trade unions or employers' organizations, but these organizations have not taken a particularly active public role. They include Pellervo Economic Research (Pellervon taloustutkimus, PTT), associated with the Central Union of Agricultural Producers and Forest Owners (Maa- ja metsätaloustuottajain Keskusliitto MTK) and the Centre Party; the Labor Institute for Economic Research (Palkansaajien tutkimuslaitos PT), associated with the Central Organization of Finnish Trade Unions (Suomen Ammattiliittojen Keskusjärjestö SAK) and the Social Democratic Party; and the Research Institute of the Finnish Economy (Elinkeinoelämän tutkimuslaitos ETLA), funded mainly by Finnish employer organizations. Each organization prepares evaluations and forecasts concerning the national economy. In contrast to the three other Nordic countries, in Finland de-corporatization and mediatization have also occurred, but possibly with different magnitudes and timescales. Moreover, the consensual political system and close relations between media and political actors might still be strong explanatory factors in the Finnish case. After presenting the results of the empirical analysis of Finnish think tanks' visibility in the media, I will discuss the specific political communication environment and culture in Finland. The aim is to see more closely why the think tanks have not appeared much in the media and why even a stalwart such as EVA makes only a modest appearance. The Finnish think tanks associated with political parties include the leftist tanks Kalevi Sorsa Foundation associated with the Social Democratic Party (SDP); the Left Forum associated with the 
Left Alliance; Suomen Toivo (Finland's Hope), associated with the National Coalition Party; e2 associated with the Center party; Visio associated with the Green Party; and Suomen Perusta (Foundation of Finland) associated with the Finns Party. Other recently founded think tanks include Magma, which is financed by Swedish-Finnish foundations, and the right-wing, neoliberal Libera, which is financed by corporate money. In addition to these advocacy think tanks, Demos Helsinki was founded in 2005 , as a non-aligned think tank that finances research on 'future society' with project funding.

EVA was established in 1974 as a policy and pro-market think tank, but started calling itself or officially became a think tank only when think tanks became a trend in Finland in the 2000s. EVA describes its mission as follows: 'EVA's aim is to identify and evaluate trends that are important for Finnish companies and for the long-term success of the society as a whole. EVA publishes reports and organizes events and discussions' (http://www.eva.fi/en/eva/). As for the think tanks associated with leftist political parties included in the analysis, the Kalevi Sorsa Foundation profiles itself as a social democratic think tank: 'describing and contributing to the conversation on what kind of social democratic policies combine freedom and justice with equality, also in the long term' (http://sorsafoundation.fi/en/). The Left Forum, established in 2006, says that it is 'building a collaborative network sharing a leftist set of values and extending from political parties to universities, research institutions and expert organizations, ${ }^{, 66}$

\section{Think tanks' role as public agenda-setters}

In contrast to a classical view of think tanks, Hart and Vromen (2008) see that think tanks' activity is no longer about producing but about locating research and no longer about getting 'leverage' for one's own ideas but about effective 'brokerage.' This refers to discursively connecting suppliers (interest groups and organizations) and consumers (politicians and office holders) in the market for policy ideas. Stone (2007, 274), along with other researchers (Cook 1998; Rich \& Weaver 2000; Osborne 2004) refers to the theory of agenda setting in connection with think tanks. Media visibility has become an important priority for nongovernment research organizations, whose principal mission is to produce and promote their expertise among policy makers (Rich \& Weaver 2000, 81). Rich and

66 (http://www.vasemmistofoorumi.fi/en/leftforum/). 
Weaver $(2000,100)$ conclude that media visibility is one of several ways through which think tanks may affect the policy-making process. As Cook $(1998,10)$ illustrates, policymakers are influenced by and to pay attention to issues and ideas covered by the news media. Stone $(2007,274)$ sees that the management of expert discourse instead of research empowers think tanks in setting agendas. The success of the new style of think tanks is measured by their ability to produce frames and narratives that begin to pervade elite rhetoric and policy proposals circulating in the policy system (Osborne 2004, 138).

Bentham (2006) sees the role of think tanks in the British context in policy agenda-setting as significant. According to him, they have a key role in constructing frameworks within which public policy problems are understood. Bentham describes how the British Institute for Public Policy Research (IPPR) and Demos, a cross-party think tank, have created coalitions, networked with the media as well as acted as independent experts that mediate between the politics of government and political parties. In addition, Stone sees that think tanks are very effective organizations for translating ideas or abstract theory into 'sound bites' for the media and understandable 'blueprints' for decision makers and the public. The constant repetition of the policy message via different formats - seminars, conferences, workshops, policy briefs, web sites, books — broadcasts and amplifies policy research (Stone 2007, 272). This has also been EVA's strategy in Finland, as the organization produces a substantial number of reports, attitude surveys and the like, as well as organizes events such as seminars and discussion forums.

\section{Think tank media visibility: empirical analysis of Finnish newspapers}

The following presents the Finnish empirical results from a comparative Nordic media analysis, in which the activity and relevance of think tanks through their agenda-setting function and media visibility were examined (see also Blach-Ørsten \& Kristensen 2016). The Finnish empirical material includes quantitative analysis of stories that appeared in the seven biggest Finnish newspapers in 2006 and 2013. As for the selection of think tanks, for all the Nordic countries, the minimum was the most important right wing (conservative/liberal advocacy think tank) and the most important left-wing advocacy think tank, if such a think tank exists. In the Finnish case, EVA was the most important, in terms of political judgment (the most influential) and the most referred to in the media. The social democratic Kalevi Sorsa Foundation and the Left Forum, associated with the Left Alliance, represent left-wing advocacy think tanks. 
In the empirical analysis, the seven highest-circulation newspapers in Finland were examined for their coverage of the specified think tanks. These newspapers included Helsingin Sanomat, Aamulehti, Turun Sanomat, Iltalehti, Maaseudun Tulevaisuus, Ilta-Sanomat and Kaleva. Articles in printed newspapers (independent of size and genre) that cited or mentioned specific advocacy think tanks were included. A code book for the Nordic comparative research was developed in co-operation with Danish, Norwegian and Swedish partners, and quantitative analysis based on this common code book was carried out in each country. A total of 44 variables were established, of which the most important are presented in this article.

A research assistant coded the material in close cooperation with the author. The coder used a logbook and wrote references to or comments on coding decisions that were initially problematic. These points were discussed with the author and, when necessary, with the other Nordic partners. This quantitative approach represents the starting point and the first analysis of the appearance of think tanks in the Finnish media. However, to understand more thoroughly how think tanks influence the public agenda and their relationship with the media, one should also conduct more in-depth qualitative analyses. The research questions addressed in this article were as follows:

1) How much and what kind of coverage do the selected think tanks receive in the selected newspapers?

2) As sources, how do the selected think tanks figure in the selected papers?

To answer these questions, the following variables were used to cover the points in the selected newspaper articles:

1) Number of stories in 2006 and 2013 per think tank

2) Percentage of news and commentary stories

3) Percentage of the coverage per think tank

4) Main topics covered in the stories

5) Role of think tanks as sources

6) Whether a story was based on a think tank's initiative

7) Tendency detected in the news and commentary stories

The seven largest Finnish newspapers included in the sample are introduced briefly here. The largest and only nationwide newspaper is Helsingin Sanomat (HS), with a circulation of 313.062 (2013), which is still quite substantial in a country of 5.5 million people. Owned by Sanoma Corporation, this 
newspaper is by far the biggest and most influential paper in the country, even if the circulation numbers have been dropping for years, consistent with the overall development of the newspaper market. The second largest newspaper is Ilta-Sanomat, with a circulation of 118.358 (2013). It is the biggest tabloid newspaper and is also owned by Sanoma Corporation. The third is Aamulehti, a daily published in Tampere, covering the Pirkanmaa region. Aamulehti has a circulation of 113.066 (2013) and is owned by Almamedia Corporation, the second largest media conglomerate in Finland. The fourth is Turun Sanomat, a daily covering the Turku region (southwest Finland). It has a circulation of 94.185 (2013), and it is owned by TS-concern. The fifth biggest paper is a paper for the rural region, Maaseudun Tulevaisuus. With a circulation of 80.750 , the paper is published by Viestilehdet Oy, which is owned by the Central Union of Agricultural Producers and Forest Owners. The sixth biggest paper is the other popular tabloid newspaper Iltalehti. It has a circulation of 77.345, and it is part of the Almamedia Corporation. The last newspaper included in the sample is Kaleva, which has a circulation of 69.540. It is a daily published in Oulu, covering northern Finland, and it is owned by Kaleva Oy.

All the newspapers declare themselves politically non-aligned, but most have historical roots with political ties. Helsingin Sanomat disengaged from partisanship early on, in the 1930s. The newspaper had been close to the liberal National Progressive Party. The tabloid Ilta-Sanomat (est. 1932) is owned by the same concern and was originally published as an afternoon edition of HS. Iltalehti was originally established as an afternoon edition of the liberal Uusi Suomi, once a competitor of HS with a background as a supporter of the right-wing National Coalition Party. The same concern owns Aamulehti and the business paper Kauppalehti. In addition, Aamulehti was an organ of the right-wing National Coalition party (until 1992). Turun Sanomat (until 1962) and Kaleva (until 1953), in turn, were supporters of the liberal National Progressive Party, later the People's Party of Finland. Maaseudun Tulevaisuus, however, which is owned by the Central Union of Agricultural Producers and Forest Owners, declares itself politically non-aligned.

\section{Still a modest presence}

Compared to the other Nordic countries, especially Denmark, the size of the Finnish data, or coverage of think tanks in the press, is small. As stated, the phenomenon only recently appeared in Finland, and the media visibility of the recently founded think tanks is not very extensive. Think tanks as a phenomenon have not (yet) captured a significant part of the public arena. EVA, the organization that 
has a longer history and has started calling itself a think tank, gets most of the visibility in the studied material. In this respect, EVA seems to be a special case.

The total number of stories for the two years 2006 and 2013 was a mere 273: $138(50.5 \%)$ and 135 (49.5\%), respectively. Thus, no significant increase in volume was detected. The stories were evenly divided into news and commentary pieces, $50.5 \%$ and $49.5 \%$, respectively. The biggest dailies published most of the stories, with Helsingin Sanomat the leader. The complete figures are presented in Table 1.

Table 1: Number of stories published in the selected newspapers in 2006 and 2013

\begin{tabular}{|l|l|l|}
\hline Helsingin Sanomat & 89 & $32.6 \%$ \\
\hline Aamulehti & 64 & $23.4 \%$ \\
\hline Turun Sanomat & 43 & $15.8 \%$ \\
\hline Iltalehti & 23 & $8.4 \%$ \\
\hline Maaseudun Tulevaisuus & 21 & $7.7 \%$ \\
\hline Ilta-Sanomat & 20 & $7.3 \%$ \\
\hline Kaleva & 13 & $4.8 \%$ \\
\hline Newspaper & Total amount & Percentage \\
\hline
\end{tabular}

Most of the stories mention EVA or use it as a source. It seems that other think tanks have not yet established themselves as credible public debaters, at least not when looking at mainstream newspapers. Stories mentioning EVA total 244, which represents $89 \%$ of the whole sample. Kalevi Sorsa Foundation was mentioned in 14 stories, representing 5\%, and the Left Forum 11 stories, representing 4\%. As the results show, the left-leaning think tanks have not yet received substantial media attention. Several other think tanks, those associated with political parties and others, were also founded in Finland in the 2000s, but they have not been very visible, either. The non-aligned Demos Helsinki, established in 2005, for example, was mentioned five stories in 2006 as well as in 2013 in the biggest paper Helsingin Sanomat.

\section{Topics and genres: EVA as an all-round expert}

The stories with the mention of one or more think tanks covered a wide range of topics and genres. The key topic, as outlined in the codebook, was defined by the title and the introductory section of the article. If this proved ambiguous or difficult to decide, the first topic mentioned was coded for. 
Secondary topics were also coded but are not presented in this article. In the Finnish data, labor market issues appeared as the most frequently discussed topic. The topics of taxes and tax regulation, social welfare and health, as well as economic and financial policy, which ranked at the top of the list, follow a similar logic as in the other Nordic countries (Allern \& Pollack 2015; Bjerke 2015; Blach-Orsten $\&$ Kristensen 2016). A unique element in the Finnish data, however, was the ranking of foreign policy and international questions as second among the themes discussed as key topics. Table 2 presents the topics discussed according to the coding categories.

The category other topics covers a surprisingly high portion of the stories, $23 \%$ (64 pieces). Among these stories, the subjects of meta news on politics or the political game totaled 16 stories. News about public figures or persons, especially the death of the former EVA leader and prominent Finnish figure Max Jakobson, totaled 21 stories.

As most of the stories involved EVA, one can conclude that EVA has promoted itself, with its prominent leader and public figure Matti Apunen (since 2010), as an expert in several societal issues, not only economic policies.

Table 2: Key topics discussed in the selected newspapers

\begin{tabular}{|l|l|l|}
\hline 1. Labor market & 40 & $14.7 \%$ \\
\hline 2. Foreign policy, international questions & 35 & $12.8 \%$ \\
\hline 3. Taxes and tax regulation & 33 & $12.1 \%$ \\
\hline 4. Social welfare and health & 25 & $9.2 \%$ \\
\hline 5. Economic and financial policy & 25 & $9.2 \%$ \\
\hline 6. Culture/popular culture/arts & 23 & $8.4 \%$ \\
\hline 7. The think tank itself & 16 & $5.9 \%$ \\
\hline 8. Marketization/privatization & 4 & $1.5 \%$ \\
\hline 9. Human rights & 4 & $1.5 \%$ \\
\hline 10. Education and/or research & 2 & $0.7 \%$ \\
\hline 11. Immigration and integration questions & 1 & $0.4 \%$ \\
\hline 12. Other ideological questions & 1 & $0.4 \%$ \\
\hline 13. Other topics & 64 & $23.4 \%$ \\
\hline Topic & Total amount & Percentage \\
\hline
\end{tabular}




\section{Think tanks as expert sources}

Think tanks as sources were categorized either as expert sources, 'special interest' sources, peripheral references or other. According to the data, newspapers often treat think tanks, especially EVA, as neutral information providers or sources, since think tanks figure as expert sources in $74 \%$ of the stories. Only in $6 \%$ of the stories did think tanks figure as special interest sources and in $13 \%$ as peripheral references. Often, a news story was based on the think tank's initiative (51\%), and in 35\% of the stories, the think tank was the main source. Other sources used as main sources in the selected news stories are presented in Table 3.

Table 3: Main sources used in the stories

\begin{tabular}{|l|l|}
\hline Think tank representative & $35 \%$ \\
\hline Other sources & $15.3 \%$ \\
\hline Politician/political party & $13.9 \%$ \\
\hline Independent, academic expert source & $10.2 \%$ \\
\hline Industry, banking, business, trade associations & $9.5 \%$ \\
\hline Trade union, interest organization, NGOs & $4.4 \%$ \\
\hline Civil servant & $4.4 \%$ \\
\hline Media source & $3.6 \%$ \\
\hline 'Ordinary citizen'/not institutional source & $3.6 \%$ \\
\hline Source & Percentage \\
\hline
\end{tabular}

$(\mathrm{N}=138)$

In the news and commentary stories, EVA receives a substantial amount of positive or affirming publicity. According to the data, EVA is a credible public discussant. The others do not have such reputation yet, as their appearance in the data is minimal. Positive tendency toward the initiatives presented by the think tanks, or tendency toward the think tanks themselves in the stories, was defined in this study as affirmative, non-critical, a major source 'getting the floor.' Of the news stories, $21 \%$ were positive, and of the commentaries, $24 \%$. Not much negative coverage was found. Instead, most of the material could be categorized as neutral, $48 \%$ of the news stories and $54 \%$ of the commentary stories, or irrelevant, in which case no particular initiative or idea was discussed in the story. The data is found in Table 4. 
Table 4: News angle and commentary tendencies in the selected newspapers

News angle tendency $(\mathrm{N}=137)$ :

\begin{tabular}{|l|c|c|}
\hline Positive about a proposal/initiative & 29 & $21.2 \%$ \\
\hline Negative about a proposal/initiative & 5 & $3.6 \%$ \\
\hline Neutral about a proposal/initiative & 66 & $48.2 \%$ \\
\hline Irrelevant/not possible to decide & 37 & $27 \%$ \\
\hline Tendency & Total amount & Percentage \\
\hline
\end{tabular}

Commentary tendency $(\mathrm{N}=135)$ :

\begin{tabular}{|l|l|l|}
\hline Positive about a proposal/initiative & 33 & $24.3 \%$ \\
\hline Negative about a proposal/initiative & 12 & $8.8 \%$ \\
\hline Neutral about a proposal/initiative & 74 & $54.4 \%$ \\
\hline Irrelevant/not possible to decide & 17 & $12.5 \%$ \\
\hline Tendency & Total amount & Percentage \\
\hline
\end{tabular}

In the following section, I discuss the background and possible explanations for the Finnish data, the rather limited overall amount of coverage of think tanks, as well as the overwhelming dominance of EVA in the coverage.

\section{EVA: an established organization and a credible public actor}

Of the three think tanks studied, EVA is clearly the forerunner in media visibility in Finnish newspapers. EVA has promoted itself, with the prominent spokesperson Matti Apunen, as an expert on several areas of societal issues, not only economic policies.

EVA has a long history, and it has built a position as a legitimate organization in Finnish society that explains EVA's role in the Finnish data, and perhaps the no longer pressing need to achieve mass publicity. As Bentham puts it, think tanks are not static institutions; they also have an historical ideational and institutional background (Bentham 2006, 168). Here it is necessary to discuss EVA's background to shed more light on its position. The organization's history starts in heavily politicized 1970s Finland. When EVA was founded, there was an effort to balance the political climate, counter leftist tendencies and try to build consensus to enhance more market-oriented and corporate-friendly policies. According to the official history of EVA, originally the organization's most important mission was to enhance and prepare for societal change, as the industrial circles were seeing a mental 
shift in society (Tarkka 2002, 99, 410). The first chairman, Max Jakobson (1974-1985), shocked Finnish society by talking about 'a dangerous neighbor', not referring to the Soviet Union, but to Sweden, and the stiffening effect of democratic socialism on Swedish society. His point was that Finland should avoid such a situation (Tarkka 2002, 113).

In the early years, EVA developed a specific strategy for media visibility and communication. Communication activities were planned in order to improve cooperation among the industrial organizations, steady article production for the press was to be established and publication activities were developed. As for the leadership of private companies, their ability and preparedness for societal discussion were enhanced by arranging meetings with politicians. The objective was also to teach chief executive officers (CEOs) and other executives to argue and state their case 'against accusations made by the press' (Tarkka 2002, 114, 127-8).

As the EVA founders noticed that the public's attitudes and ways of thinking could not be influenced by traditional public affairs, PR activities or lobbying, EVA concluded that they could be influenced by 'absolute publicity,' even if the (initial) attention was negative. EVA was able to present in public the most important aspects of its program, and did so in a very visible way, even though initially the presentation did not have much effect. EVA events and reports received major publicity at the time. Tarkka establishes that the comments in the media were initially belittling and negative, but the ideas EVA presented were publicized and 'planted a seed' (Tarkka 2002, 410-11). For example, EVA's attitude surveys of Finns have over many decades earned it the label of a credible information provider. In addition to media attention, EVA has other outlets and forums in which to spread the organization's ideas more effectively and exert influence. Today, EVA is tightly woven in the other power structures of Finnish society and has a strong position in the public that gives the organization some leverage. The chairman and spokesperson of EVA since 2010, Matti Apunen, as a former editor-in-chief of Aamulehti and a columnist of Helsingin Sanomat, has a clear spot in the public light when necessary.

\section{An all-round networked organization}

Apart from media attention, having solid networks in Finnish society makes it easier to reach a large ground when advocating a policy idea. EVA is directly associated with the interests of economic life and Finnish employers' organizations, and is obviously well funded. EVA is closely affiliated with the research organization ETLA and the employers' organization EK. In the 1970s, at the time of EVA's founding, Tarkka sees that ETLA's public commentary and appearances, as they were 
scientific and thus were presented as objective, did not carry far in public debate, which was highly political and subjective at the time (Tarkka 2002). In addition, ETLA did not react as quickly as dayto-day debate required. ETLA's role was not to be polemic or confrontational, but the organization could nevertheless be clearly pro-business. When EVA came along, ETLA's role next to EVA would be to concentrate on topical societal issues, but ETLA's main task would be conducting economic research alongside EVA - in the same way that the employers' organizations performed economic policy lobbying (Tarkka 2002, 101-2).

One of EVA's objectives from the start was follow-up and analysis of the political situation and landscape, and through that creating working relationships with political parties, their leadership, as well as their background forces (Tarkka 2002, 112). In addition, the aim of the socio-political activities of EVA was to stay informed by creating contacts with the government and the parliament and thus improve opportunities to influence policy. EVA created close connections to the Social Democratic party, and there was a clear change in the party's economic policy in the 1970s (Tarkka 2002, 413). EVA's most important channel of influence went through the party (Tarkka 2002, 413), and in 1977, the effort to form a consensus on economic policy issues between the most important political actors in society resulted in the Korpilampi conference. Close cooperation between EVA and the more right-leaning Social Democrats was paramount for the consensus that was formed, in order to agree on tax cuts for corporations and a moratorium on pay raises for employees in the name of national competitiveness (Saari 2010, 475; Lounasmeri \& Ylä-Anttila 2014). Since then, EVA has used experts from different political backgrounds to conduct research reports, for example, Osmo Soininvaara, a former Green minister. In addition, internationally, EVA has developed a large network. During the period of Finland's gradual economic and political opening up and structural reform, Jakobson was followed by Kauko Sipponen as chairman (1984-1990). He started creating connections to organizations parallel to EVA. In 1987, EVA joined the European League for Economic Cooperation (Tarkka 2002, 331). Since Jaakko Iloniemi started as chairman for EVA in 1990, EVA has developed networks abroad and in Finland. EVA has sister organizations around the world and has established fellow programs to connect with senior and younger experts and decision makers in Finnish society.

After Finland joined the European Union (EU) in 1995, there was a quieter phase in EVA's activities, as many of EVA's objectives had been fulfilled. A new rise came in the 2000s. The new chairman Risto E.J. Penttilä (2002-2010) tried to engage in public discussion in a dynamic and provocative way, but did, in the end, not have enough credibility as a public figure. It also seemed he 
had a profile as too right-wing or ultraliberal to appear convincing. In the current atmosphere, the former editor-in-chief of Aamulehti, Matti Apunen, seems to be the right kind of personality to attract the masses with his pragmatic, down-to-earth and no-nonsense attitude. His style is often provocative, and he also gets involved in subjects of daily life such as day care, which also have to do with value questions. With Matti Apunen, EVA has raised its profile and visibility considerably, even if the overall coverage is not large.

\section{The lack of public attention for think tanks in the big picture}

As stated, EVA is a special case among the Finnish think tank scene, and it is worthwhile to ponder why the other organizations, which are mostly advocacy think tanks or think tanks associated with political parties, have not received much public attention.

Fundamentally, the characteristics of the Finnish political culture and system as still consensual and corporatist, influence the relations between media and politics. The Finnish political system and landscape can be described as still very consensus-oriented (for example, Pfetsch et al 2014; Herkman 2011; Kantola 2011). The political consensus tradition in Finland has been and still seems to be particularly strong compared to the other Nordic countries. In the Finnish parliamentary system, governments have been frequently formed over the left-right border instead of alternating dominance of either the left or right. Thus, there is no tradition of block politics. This has meant that the three big parties - until the parliamentary elections of 2011 when the Finns Party reached big party statusthe Centre Party, the National Coalition Party and the Social Democratic Party-have had to cooperate with the other two, if they want to form a government (Moring 2008, 46; Pfetsch et al 2014, 38). In addition, the Finnish welfare state was formed under the influence of various parties in coalition governments, together with a strong influence of corporatist interests, instead of being a construction of the leftist parties (Moring 2008, 46).

This decision-making culture entails a multitude of political actors relevant to political communication. One can also refer to network corporatism as a typical feature of the Nordic countries, where societal actors on a large scale gather to participate in policy processes (though in Finland the official parliamentary committee system has been dismantled). This could be hypothesized to lead to greater perceived autonomy of journalists, since the number of political actors who serve as a reference group to journalists is higher than in Southern European countries, such as France and Spain, or German-speaking countries, such as Germany and Switzerland (Pfetsch et al 2014). In Finland, the connections between media and political actors are still seemingly direct. 
Political journalists generally have direct access to the political leaders, including the prime minister. There has been a gradual weakening of political parallelism since the 1980s, as journalists have distanced themselves from the political elite (Aula 1992, Pitkänen 2009). Newspapers gradually downplayed their political affiliations, and today, the political party press is quite marginalized (Tommila \& Salokangas 1998). In 2008, Moring described the Finnish media landscape as still traditional in accordance with the democratic-corporatist model, even though there has been a clear development toward commercialization. He described the position of newspaper subscriptions, as well as public service radio and television, as still strong among the public. As for commercial television, it has not introduced a radically different news agenda despite its growing role since the 1990s (Moring 2008, 56). Thus, despite the weakening of ties, the media has not developed a markedly independent agenda, even if it has tried to take significant steps to distance itself from political power, as witnessed in connection with recent political scandals. This might, however, represent a generational question as younger journalists have taken up a more critical and challenging attitude toward politicians (Kantola 2011). In addition, reporting scandals might represent a rupture in normal day-to-day news work where connections and ties are in place.

One must also take up the point of the relevance and significance of public debate and media attention in policy processes in the Finnish case. Other forums might be more important when it comes to decision making in the Finnish polity. Being able to influence the actual political decisionmaking processes is still a very different matter, as they are often performed away from the public eye in elite circles (see for example Kunelius et al 2009). When talking about the relevance of the media presence of think tanks and of their expert role in the public sphere, Rich $(2004,139)$ has shown that the think tanks that are most widely cited in the mass media in the U.S. context are not seen by policy-makers themselves as particularly influential. According to him, 'it is easy to confuse high visibility in public arenas with high impact in the real corridors of power, where different laws of demand and supply and different concepts of utility from those prevailing in the mass media arena apply' (Rich 2004, 139). In a book on European political communication cultures, Pfetsch et al (2014, 95) conclude that Finland represents countries where there is a strong reliance on backstage agendasetting strategies.

As for the think tanks themselves, for a large part, they are directly linked to certain political parties, possibly making them mouthpieces for a particular apparatus in the eyes of the media and the public. When bringing up ideas in political discussions, if the think tanks seem to be linked to the respective parties, they do not necessarily receive more popular support. In 2012, the leading national 
newspaper Helsingin Sanomat wrote in an editorial that, thus far, think tanks had not been able to meet the expectations placed on them (HS 4.6.2012). They had not become engines for societal debate. Even if their publications and events sometimes made it into the news and aroused more general interest, they still primarily spoke to their own party activists. Moreover, the resources of these think tanks are not enormous, and they have limited staff. As this research focused on the offline versions of the analyzed newspapers, the social media activities of think tanks were not accounted for. These organizations use social media channels in their publicity work, but this has not amounted to receiving much attention in the mainstream media — at least not thus far. Overall, the breakthrough of Finnish think tanks into the mainstream media is still waiting to happen.

\section{References}

Ajatushautomoiden idea on hämärtymässä (The Idea of Think Tanks Is Obscuring) (2012). Helsingin Sanomat Editorial 4.6.2012.

Allern, S 2011, 'PR, politics and democracy', Central European Journal of Communication, vol. 4, No 1 (6).

Allern, S \& Pollack, E 2015, Swedish think tanks in the press. Paper presented in the Nordmedia conference, Copenhagen 13.8.2015.

Aula, MK 1992 'Perässä tullaan Amerikka? - Ajatuskoe suomalaisen poliittisen julkisuuden murroksesta' (Following after America? A Thought Experiment on the Finnish Public Sphere), Tiedotustutkimus 15 (2): 10-23.

Bentham, J 2006, 'The IPPR and Demos: Think Tanks of the New Social Democracy', The Political Qarterly, Vol. 77, No 2, April-June 2006.

Bjerke, P 2015, Norwegian advocacy think tanks in the media. Paper presented in the Nordmedia conference, Copenhagen 13.8.2015.

Blach-Orsten, M \& Kristensen, N 2015, Think tanks in Denmark - Media Visibility and Network Relations. Paper presented in the Nordmedia conference, Copenhagen 13.8.2015.

Braml, J 2004, US and German Think-Tanks, Nomos, Baden-Baden.

Braml, J 2006, 'U.S. and German Think Tanks in Comparative Perspective', German Policy Studies, Vol. 3, Nr 2, pp. 222-267.

Cottle, S (ed.) 2003, News, public relations and power. London: Sage.

Cook, TE 1989, Making Laws and Making News: Media Strategies in the U.S. House of Representatives, Washington D.C., Brookings Institution. 
Davis, A 2007, The mediation of power, London, Routledge.

Hart, P \& Vromen, A 2008, 'A New Era for Think Tanks in Public Policy? International Trends, Australian Realities', The Australian Journal of Public Administration, vol.67, no.2, pp.135-148.

http://sorsafoundation.fi/en/ (accessed 15.9.2015).

http://www.eva.fi/en/eva/ (accessed 15.9.2015).

http://www.vasemmistofoorumi.fi/en/leftforum/ (accessed 15.9.2015).

Kantola, A 2011, 'Notkean journalismin nousu' (Rise of Liquid Journalism), in A. Kantola (ed.), Hetken hallitsijat. Julkinen elämä notkeassa yhteiskunnassa (Rulers of the moment. Public Life in Liquid Society), Helsinki, Gaudeamus.

Keohane, RO \& Nye, JS 1998, 'Power and Interdependence in the Information Age', Foreign Affairs, Vol. 77, No. 5.

Kunelius, R, Reunanen, E \& Noppari E 2009, Media Vallan Verkoissa (Media in the Webs of Power), Series A 112/2009, Research Centre for Journalism, University of Tampere.

Lounasmeri, L \& Ylä-Anttila, T 2014, 'Ruptures in National Consensus: Economic versus Political Openness in the Globalization Debate in Finland'. In N Götz \& C Marklund, C. (eds.), The Paradox of Openness. Transparency and Participation in Nordic Cultures of Consensus, Leiden, Brill.

McGann, JG 2007, Think Tanks and Policy Advice in the United States. Academics, advisors and advocates, Abingdon \& New York, Routledge.

McGann, JG \& Johnson, EC 2005, Comparative Think Tanks, Politics and Public Policy, Cheltenham, UK, Edward Elgar Publishing Limited.

McGann, JG \& Weaver, RK (eds.) 2000, Think tanks and Civil Societies: Catalysts for Ideas and Action, London, Transaction Publishers.

Moring, T 2008, 'Media and Politics in Finland', in J Strömbäck, M Orsten \& T Aalberg (eds.), Communicating Politics. Political Communication in the Nordic Countries, Gothenburg, Nordicom. Osborne, T 2004, 'On mediators: Intellectuals and the Ideas Trade in the Knowledge Society', Economy and Society 334:430-447.

Pfetsch, B, Mayerhöffer, E \& Moring, T 2014, 'National or Professional? Types of Political Communication Cultures across Europe', in B Pfetsch (ed.), Political Communication Cultures in Europe. Attitudes of Political Actors and Journalists in Nine Countries, UK, Palgrave McMillan.

Pitkänen, V 2009 'Politiikan journalismin yhteiskunnallinen tehtävä' (The Task of Political Journalism in Society), in V Pernaa, MK Niemi \& V Pitkänen (eds.), Politiikan journalismin tila suomessa (The State of Political Journalism in Finland), Turku, Kirja-Aurora. 
Ricci, DM 1993, The Transformation of American Politics: The New Washington and the Rise of Think Tanks, New Haven, CT, Yale University Press.

Rich, A 1999, Think Tanks, Public Policy, and the Politics of Expertise, Ph.D. diss., Yale University. Rich, A 2004, Think Tanks, Public Policy and the Politics of Expertise, Cambridge, Cambridge University Press.

Rich, A \& Weaver, RK 2000, 'Think Tanks in the U.S. Media', Press/Politics 5 (4): 81-103.

Rommetvedt, H, Thesen, G, Christiansen, PM \& Nørgaard AS 2012, 'Coping With Corporatism in Decline and the Revival of Parliament: Interest Group Lobbyism in Denmark and Norway, 1980 2005', Comparative Political Studies, April 2013; vol. 46, 4: pp. 457-485.

Saari, J 2010, 'Suomalainen konsensus: Korpilammen konferenssi (1977) käännekohtana' (The Finnish consensus: The conference of Korpilampi (1977) as a turning point), Yhteiskuntapolitiikka no. 5: 469-487.

Smith, JA 1991, The Idea Brokers: Think Tanks and the Rise of the New Policy Elite, New York, Free Press.

Stone D 2007, 'Recycling bins, garbage cans or think tanks? Three myths regarding policy analysis institutes', Public Administration Vol.85, No.2, 2007 (259-278).

Tarkka, J 2002, Uhan alta unioniin. Asennemuutos ja sen unilukkari EVA (To the Union Underneath the Threat. Change in Attitudes and its Facilitator EVA), Helsinki, Otava.

Thunert, MW 2004, 'Think tanks in Germany', in D Stone \& A Denham (eds), Think Tank Traditions: Policy Research and the Politics of Ideas, Manchester, Manchester University Press, 71-88.

Tommila, P \& Salokangas, R 1998, Sanomia kaikille. Suomen lehdistön historia (News to Everyone. The History of the Finnish Press], Helsinki, Edita.

Tyllström, A 2013, Legitimacy for Sale. Constructing a Market for PR Consultancy, Företagsekonomiska institutionen, Uppsala Universitet.

Warpole, K 1998, 'Think-Tanks, Consultancies and Urban Policy in the UK', International Journal of Urban and Regional Research 22(1): 147-155.

Weaver, RK 1989, 'The Changing World of Think Tanks', P.S.: Political Science and Politics 22 (3): 563-79. 